\title{
EFEKTIVITAS PENERAPAN MODEL PEMBELAJARAN KOOPERATIF TIPE JIGSAW BERBANTUAN MIND MAP TERHADAP KEMAMPUAN PEDAGOGIK MAHASISWA MATA KULIAH PENGEMBANGAN PROGRAM DIKLAT
}

\author{
Putri Khoirin Nashiroh'), Fitria Ekarini'2), Riska Dami Ristanto ${ }^{3)}$ \\ 123 Fakultas Teknik, Universitas Negeri Semarang
}

Email: putrikhoirin@mail.unnes.ac.id, fitriaekarini@mail.unnes.ac.id, rdristanto@mail.unnes.ac.id

\begin{abstract}
ABSTRAK
Kemampuan pedagogik merupakan kemampuan dasar yang harus dimiliki mahasiswa dalam menempuh mata kuliah Pengembangan Program Diklat. Tujuan dari penelitian ini adalah untuk: (1) mengetahui pengaruh dari penerapan model pembelajaran kooperatif tipe jigsaw berbantuan mind map terhadap kemampuan pedagogik mahasiswa pada mata kuliah Pengembangan Program Diklat; dan (2) mengetahui efektivitas penerapan model pembelajaran kooperatif tipe jigsaw berbantuan mind map terhadap kemampuan pedagogik mahasiswa pada mata kuliah Pengembangan Program Diklat. Metode penelitian yang digunakan pada penelitian ini adalah kuantitatif deskriptif dengan desain penelitian pre-eksperimental yang melibatkan 1 kelas eksperimen. Hasil rata-rata pretes adalah 50,26 dan rata-rata postes adalah 78,07. Hasil uji-t sampel berpasangan pretes-postes menghasilkan nilai Sig. sebesar 0,000 yang menunjukkan bahwa ada perbedaan rata-rata secara signifikan hasil pretes dengan postes. Persentase respon mahasiswa terhadap penerapan model pembelajaran sebesar $87,21 \%$. Hasil Nilai $N$-Gain menunjukkan persentase $56 \%$. Kesimpulan dari penelitian ini adalah ada pengaruh yang signifikan penerapan model pembelajaran kooperatif tipe jigsaw berbantuan mind map terhadap kemampuan pedagogik mahasiswa dengan kategori efektivitas peningkatan kemampuan pedagogik cukup efektif dan kategori respon mahasiswa sangat efektif.
\end{abstract}

Kata kunci: Model Pembelajaran Kooperatif, Jigsaw, Mind Mapping, Kemampuan Pedagogik, Program Diklat

\begin{abstract}
Pedagogic ability is a basic ability that must be possessed by students in taking courses in the Development of Training Programs. The purpose of this study is to: (1) determine the effect of the application of the Jigsaw type cooperative learning model with a mind map to the pedagogical ability of students in developing courses in Education and Training Programs; and (2) knowing the effectiveness of applying the Jigsaw type cooperative learning model with a mind map to the pedagogical abilities of students in the Training Program Development course. The research method used in this research is quantitative descriptive with a pre-experimental research design involving one class of experiments. The average pretest yield was 50.26 and the average posttest was 78.07. The results of the t-test paired samples pretest-posttest produced Sig. of 0.000 which shows that there is a significant difference in the average of the pretest and posttest results. The percentage of student responses to the application of the learning model was $87.21 \%$. The results of the $\mathrm{N}$-Gain Value show a percentage of $56 \%$. The conclusion of this study is that there is a significant influence on the application of a type of jigsaw-assisted cooperative learning model to the pedagogical abilities of students with the effectiveness category of improving pedagogical abilities quite effectively and the category of student responses is very effective.
\end{abstract}

Keywords : Cooperative Learning, Jigsaw, Mind Mapping, Pedagogic Ability, Training Programs. 


\section{PENDAHULUAN}

Perguruan tinggi merupakan satuan pendidikan penyelenggara jenjang pendidikan tertinggi di Indonesia. Perguruan tinggi menghasilkan lulusan yang siap mengabdi kepada masyarakat. Oleh karena itu, kualitas lulusan perguruan tinggi perlu diperhatikan. Termasuk lulusan dari Perguruan Tinggi yang tergolong pada Lembaga Pendidikan Tenaga Keguruan (LPTK). Mereka dituntut agar memiliki kompetensi guru. Kompetensi guru sebagai agen pembelajaran meliputi kompetensi pedagogik, kompetensi kepribadian, kompetensi professional dan kompetensi sosial [1].

Kompetensi pedagogik merupakan kemampuan yang berkenaan dengan pemahaman peserta didik dan pengelolaan pembelajaran yang mendidik dan dialogis [1]. Kompetensi tersebut meliputi pemahaman terhadap peserta didik, perancangan dan pelaksanaan pembelajaran, evaluasi hasil belajar, dan pengembangan peserta didik untuk mengaktualisasikan berbagai potensi yang dimilikinya. Penelitian oleh Prasetyo dan Kusumantoro [2] memberikan hasil bahwa ada pengaruh positif kompetensi pedagogik terhadap prestasi belajar kewirausahaan siswa kelas X Tata Niaga SMK Negeri 1 Salatiga. Hal ini menunjukkan bahwa seorang pendidik harus menguasai kemampuan pedagogik agar memiliki kontribusi yang positif terhadap prestasi hasil belajar peserta didik.

Program studi S1 Pendidikan Teknik Informatika dan Komputer merupakan salah satu program studi kependidikan yang berada di Jurusan Teknik Elektro Universitas Negeri Semarang. Salah satu profil lulusannya adalah menjadi seorang pendidik yang profesional di bidang Teknik Informatika dan Komputer, baik di jenjang pendidikan formal maupun non formal. Oleh karena itu, sebagai calon pendidik, mahasiswa pada program studi ini dituntut harus menguasai kompetensi pendidik, termasuk memiliki kemampuan pedagogik. Hal tersebut selaras dengan hasil penelitian yang dilakukan oleh Supriyono [3] dengan kesimpulan bahwa semakin tinggi kompetensi pedagodik maka kinerja pendidik juga tinggi dalam mencapai tujuan pendidikan.

Salah satu mata kuliah yang diambil oleh mahasiswa pada semester 6 adalah Pengembangan Program Diklat. Program diklat adalah rancangan suatu sistem dalam proses pengubahan sikap dan tata laku seseorang maupun peningkatan atau perolehan kemahiran (ketrampilan) dalam rangka pendewasaan melalui upaya pengajaran dan pelatihan [4]. Lebih lanjut dijelaskan bahwa program diklat merupakan cerminan dari pengalaman-pengalaman belajar apa saja yang harus ditimba oleh peserta berdasarkan tujuan yang akan dicapai, baik dari aspek pengetahuan, keterampilan, maupun sikap yang terintegrasi dalam satu proses pembelajaran pada materi diklat. Berdasarkan penjelasan tersebut, dapat dipastikan bahwa mahasiswa Program Studi Pendidikan Teknik Informatika dan Komputer harus memiliki kemampuan pedagogik agar mereka dapat merencanakan tugas pengembangan program diklat dengan melibatkan ilmu pedagogik di dalamnya, sehingga tujuan dari perencanaan, pengembangan, dan pelaksanaan program diklat dapat tercapai dengan baik.

Keadaan yang terjadi di kelas saat proses pembelajaran pada mata kuliah pengembangan program diklat menunjukkan bahwa respon mahasiswa terhadap kompetensi pedagogik masih kurang, yang ditunjukkan dengan rata-rata nilai pretest yang masih rendah. Beberapa permasalahan yang terjadi selama proses pembelajaran di kelas antara lain: (1) rendahnya antusias mahasiswa dalam mengikuti kegiatan pembelajaran pada mata kuliah kependidikan, sehingga proses pembelajaran menjadi kurang efektif; (2) kurangnya pemahaman mahasiswa mengenai ilmu pedagogik sehingga akan berdampak pada proses pembelajaran mata kuliah lain yang masih berhubungan dengan ilmu pedagogik, misalnya Mata Kuliah Pengembangan Program Diklat; dan (3) kurangnya kompetensi pedagogik pada mahasiswa yang meliputi sikap, pengetahuan dan keterampilan dalam mengajar dan presentasi di kelas. Sebagai upaya untuk menyelesaikan beberapa permasalahan di atas maka diperlukan suatu usaha penguatan kemampuan pedagogik mahasiswa pada Mata Kuliah Pengembangan Program Diklat.

Banyak faktor yang dapat mempengaruhi keberhasilan belajar. Salah satu faktor yang mungkin berpengaruh adalah pemilihan model pembelajaran yang tepat untuk proses pembelajaran di kelas. Model pembelajaran yang berpusat pada peserta didik dapat dijadikan solusi agar kegiatan pembelajaran di kelas dapat berjalan dengan optimal [5]. Pemilihan model pembelajaran yang tepat, diharapkan dapat meningkatkan antusias mahasiswa sebagai peserta didik dalam mengikuti kegiatan pembelajaran mata kuliah kependidikan seperti Pengembangan Program Diklat. Salah satu model pembelajaran yang dapat digunakan untuk mengaktifkan peserta didik adalah model pembelajaran kooperatif. Pembelajaran kooperatif adalah model pengajaran yang mengkondisikan peserta didik untuk bekerja sama dalam kelompok kecil dan saling membantu dalam belajar [6]. Hasil penelitian yang dilakukan oleh Gull dan Shehzad [7] menunjukkan bahwa kegiatan pembelajaran kooperatif memiliki efek positif terhadap prestasi akademik. 
Peran aktif peserta didik dalam kegiatan pembelajaran koperatif yang menyenangkan diharapkan dapat meningkatkan pemahaman peserta didik terhadap materi yang dipelajari, terutama untuk materi yang sifatnya teoritis. Kerja sama akan efektif ketika peserta didik menyadari bahwa mereka berbagi target yang sama dan memiliki target individu secara positif untuk berkontribusi terhadap proses pembelajaran kelompok. Pembelajaran kooperatif tipe Jigsaw adalah praktik mengajar di mana peserta didik bertanggung jawab untuk mempelajari materi dan mengajarkannya kepada peserta didik lainnya [8]. Hal ini mendorong partisipasi peserta didik untuk mendukung keberhasilan proses pembelajaran. Keberhasilan tersebut tergantung pada kerja sama aktif dan partisipasi dari semua anggotanya. Jigsaw dapat meningkatkan aktivitas peserta didik [9].

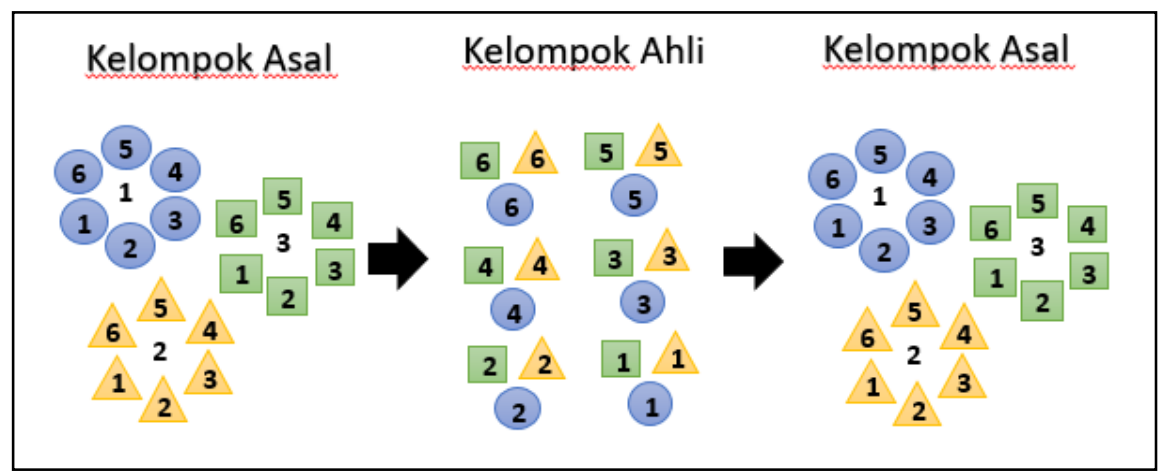

Gambar 1. Gambaran Tahapan Model Pembelajaran Kooperatif Tipe Jigsaw

Tahapan model pembelajaran Kooperatif tipe Jigsaw dapat dilihat pada Gambar 1. Tahapan jigsaw pada penelitian ini adalah: (1) membentuk kelompok asal dan memberi nomor urut yang berbeda pada setiap mahasiswa dalam kelompok, (2) Setiap mahasiswa pada kelompok asal mendapatkan materi yang berbeda sesuai dengan nomor; (3) Setiap mahasiswa yang memiliki nomor yang sama bergabung membentuk kelompok ahli untuk mempelajari materi dengan topik yang sama; (4) Masing-masing mahasiswa pada kelompok ahli kembali ke kelompok Asal untuk menjelaskan materi; (5) Evaluasi. Tahapan pembelajaran di atas merupakan tahapan umum dari jigsaw [5][8][10]. Melalui model pembelajaran ini diharapkan setiap mahasiswa akan memiliki tanggung jawab untuk belajar dan menyampaikan hasilnya kepada rekan sekelompoknya. Selain itu, mahasiswa akan lebih nyaman untuk menyampaikan ide dan pertanyaan berkaitan dengan materi yang belum mereka ketahui kepada sesama temannya, sehingga materi tentang pedagogik dapat dikuasai dengan baik.

Upaya lain agar pembelajaran berpusat kepada peserta didik adalah dengan menggunakan Mind Map. Mind map merupakan cara mudah untuk menempatkan informasi kedalam otak dan mengambil informasi ke luar dari otak, sehingga dapat menghasilkan cara untuk mencatat yang kreatif dan efektif sesuai dengan peta pikiran kita [11]. Mind mapping menuntut peserta didik untuk lebih aktif mengkonstruksi pemahamannya ke dalam suatu peta konsep berdasarkan permasalahan yang diberikan oleh pendidik [12]. Mind map diharapkan dapat memudahkan peserta didik dalam menyusun dan menjelaskan konsep yang ada di dalam pikirannya kepada teman-temannya terkait dengan materi yang ditugaskan di kelompok, karena ide pokok dan gambaran seluruh materi sudah tergambar dengan jelas pada mind map.

Implementasi model kooperatif tipe jigsaw dengan penugasan mind map secara signifikan lebih dapat meningkatkan penguasaan konsep dan kemampuan berpikir kreatif peserta didik dibandingkan dengan implementasi model konvensional dengan penugasan mind map [16]. Pembelajaran kooperatif tipe jigsaw berbantuan mind map diharapkan dapat menjadi suatu solusi agar mahasiswa dapat menguasai materi pedagogik dengan baik, sehingga pengembangan program diklat dapat dilakukan dengan baik pula. Adapun tahapan-tahapan model pembelajaran kooperatif tipe jigsaw berbantuan mind map pada penelitian ini adalah sebagai berikut: (1) membentuk tim asal disertai dengan pemberian penomoran; (2) memberikan topik materi yang berbeda pada setiap mahasiswa pada kelompok asal berdasarkan nomor yang didapat; (3) Mahasiswa dengan nomor yang sama berkumpul ke dalam kelompok ahli untuk mendiskusikan materi dan membuat mind map-nya; (4) hasil mind map dikumpulkan dan ditempel di dinding; (4) Setiap mahasiswa kembali ke kelompok asal, secara bergiliran menjelaskan materi sesuai pembagian pada kelompok ahli dengan bantuan mind map yang telah dibuat.

Berdasarkan pemaparan masalah dan teori yang telah disampaikan, maka tujuan dari penelitian ini antara lain untuk: (1) mengetahui pengaruh dari penerapan model pembelajaran kooperatif tipe jigsaw berbantuan mind map terhadap kemampuan pedagogik mahasiswa pada mata kuliah 
Pengembangan Program Diklat; dan (2) mengetahui efektivitas penerapan model pembelajaran kooperatif tipe jigsaw berbantuan mind map terhadap kemampuan pedagogik mahasiswa pada mata kuliah Pengembangan Program Diklat.

\section{METODE}

Metode yang digunakan pada penelitian ini adalah kuantitatif deskriptif. Penelitian menggunakan desain Pre-Experimental, yaitu One-Group Pretest-Posttest Design. Penelitian ini hanya melibatkan 1 kelas eksperimen tanpa kelas kontrol. Desain ini membandingkan keadaan sebelum dan sesudah diberi perlakuan, yaitu membandingkan nilai pretest dengan nilai posttest. Desain penelitian dapat dilihat pada Tabel 1.

Tabel 1. Desain Penelitian Eksperimen One-Group Pretest-Posttest

\begin{tabular}{lccc}
\hline Kelompok & Pretest & Perlakuan & Posttest \\
\hline Eksperimen & $\mathrm{O}_{1}$ & $\mathrm{X}$ & $\mathrm{O}_{2}$ \\
\hline
\end{tabular}

Tahapan-tahapan kegiatan penelitian dirancang berdasarkan desain pada Tabel 1. Tahapan pertama dari eksperimen ini adalah memberikan pretest kepada mahasiswa. Tahapan selanjutnya adalah memberikan perlakuan kepada mahasiswa pada kelompok eksperimen berupa penerapan model pembelajaran kooperatif tipe jigsaw pada materi pedagogik model dan strategi pembelajaran, dan penerapan model pembelajaran kooperatif tipe jigsaw berbantuan mind map pada materi evaluasi hasil belajar. Tahapan kegiatan eksperimen diakhiri dengan memberikan posttest dan angket respon terhadap pelaksanaan perlakuan.

Variabel pada penelitian ini berupa variabel bebas dan variabel terikat. Variabel bebas yaitu model pembelajaran kooperatif tipe jigsaw berbantuan mind map. Sedangkan variabel terikatnya adalah kemampuan pedagogik mahasiswa pada mata kuliah pengembangan program diklat.

Populasi yang digunakan pada penelitian ini adalah seluruh mahasiswa semester 6 program studi Pendidikan Teknik Informatika dan Komputer mata kuliah Pengembangan Program Diklat pada semester Genap tahun ajaran 2018-2019 sebanyak 3 rombel dengan jumlah siswa 58. Selanjutnya dilakukan pengambilan sampel secara acak menggunakan teknik simple random sampling. Berdasarkan pengambilan sampel diperoleh rombel 2 sebagai sampel untuk kelompok eksperimen, yaitu sebanyak 19 orang.

Instrumen penelitian yang digunakan pada penelitian ini antara lain tes dan angket. Instrumen tes digunakan untuk pengukuran kemampuan pedagogik mahasiswa, yaitu pada saat pretest dan posttest. Bentuk tes yang digunakan adalah soal obyektif yang terdiri dari soal pilihan ganda, truefalse, dan isian singkat. Soal obyektif berjumlah 30 soal dikerjakan berbantuan media online socrative. Indikator pada kisi-kisi soal dibuat dengan mempertimbangkan tingkatan sub CPMK dalam taksonomi bloom, sehingga soal tes tersebut sesuai dengan sub CPMK dan dapat mengukur kompetensi mahasiswa sesuai dengan capaian pembelajaran mata kuliahnya. Instrumen angket digunakan untuk melihat respon mahasiswa mengenai model pembelajaran kooperatif tipe jigsaw dan jigsaw berbantuan mind map yang diterapkan selama melaksanakan penelitian. Indikator pada angket disusun untuk melihat tingkat keterlaksanaan dan kebermanfaatan dari model pembelajaran yang digunakan sebagai variabel bebas. Angket terdiri dari 20 butir pernyataan berkaitan dengan keterlaksanaan dan kebermanfaatan model pembelajaran kooperatif tipe jigsaw dan 5 butir penyataan berkaitan dengan kebermanfaatan model pembelajaran kooperatif tipe jigsaw berbantuan mind map. Instrumen menggunakan skala likert dengan rentangan nilai sebagai berikut: (1) nilai 4 untuk SS (sangat setuju); (2) nilai 3 untuk S (setuju); nilai 2 untuk TS (tidak setuju); dan nilai 1 untuk STS (sangat tidak setuju). Pada angket juga disediakan kolom komentar dan saran mengenai pelaksanaan dari perlakuan variabel bebas.

Data kemampuan pedagogik awal mahasiswa diperoleh melalui pretest. Data kemampuan pedagogik setelah adanya perlakuan variabel bebas diperoleh melalui posttest. Dari data tersebut, selanjutnya dilakukan analisis data untuk melihat ada dan tidaknya pengaruh/perbedaan yang signifikan pada variabel terikat sebelum dan setelah dilakukan perlakuan variabel bebas. Selain itu skor pretest dan posttest juga digunakan untuk melihat efektivitas pembelajaran sebagai hasil dari perlakuan variabel bebas.

Uji hipotesis pengaruh variabel bebas terhadap variabel terikat dilakukan dengan menggunakan Uji Paired Sample T-Test. Uji ini digunakan untuk membandingkan hasil posttest terhadap hasil pretest. Uji asumsi yang disyaratkan sebelum melaksanakan uji hipotesis adalah uji normalitas, menggunakan Uji Shapiro-Wilk. Uji hipotesis Paired Sample T-Test bisa dilaksanakan jika data 
terdistribusi normal. Jika tidak terdistribusi normal uji hipotesis dilakukan dengan mengunakan statistik non parametrik berupa uji wilcoxon. Uji hipotesis dan uji asumsinya dilakukan dengan bantuan SPSS 20. Adapun Ho dari penelitian ini adalah tidak ada perbedaan rata-rata yang signifikan antara kemampuan pedagogik mahasiswa pada saat pretes dan postes.

Efektifitas dari penggunaan model pembelajaran dapat dilihat dari beberapa hal, antara lain: (1) hasil respon mahasiswa terhadap model pembelajaran yang diterapkan; dan (2) Hasil perhitungan nilai $\mathrm{N}$-Gain. Teknik analisis data yang digunakan pada hasil angket berupa analisis deskriptif. Analisis ini digunakan untuk melihat efektifitas dari model pembelajaran berdasarkan dari tingkat keterlaksanaan dan kebermanfaatannya. Hasil dari analisis ini berupa persentase secara keseluruhan respon setiap mahasiswa terkait dengan perlakuan variabel bebas. Rumus untuk menghitung skor persentase dapat dilihat pada Rumus 1. Dari persentase tersebut kemudian bisa dikategorikan tingkat efektivitasnya berdasarkan levelnya. Kriteria tingkat efektivitas dapat dilihat pada Tabel 2.

$$
P=\frac{\sum \text { all of questionaire answer }}{\text { (number of questionaire items } x \text { highest score } x \text { number of respondents) }}
$$

Tabel 2. Kriteria Efektivitas Hasil Respon Mahasiswa

\begin{tabular}{ll}
\hline Skor (Persen) & Tingkat Keefektivan \\
\hline $0-20$ & Sangat Tidak Efektif \\
$21-40$ & Tidak Efektif \\
$41-60$ & Kurang Efektif \\
$61-80$ & Efektif \\
$81-100$ & Sangat Efektif \\
\hline \multicolumn{2}{c}{ sumber: Akbar dalam Nashiroh et al. [13] }
\end{tabular}

Tingkat efektivitas selanjutnya dapat dihitung dari nilai $N$-Gain. Rumus untuk menghitung nilai $\mathrm{N}$-Gain dapat dilihat pada Rumus 2. Kriteria nilai $\mathrm{N}$-Gain dapat dilihat pada Tabel 3. Sedangkan Kategori tafsiran efektivitas berdasarkan Nilai $N$-Gain dapat dilihat pada Tabel 4.

$$
\text { Gain Score }=\frac{(\% \text { skor rerata postest }-\% \text { skor rerata pretest })}{(100 \%-\% \text { skor rerata pretest })}
$$

Tabel 3. Kriteria N-Gain Score

\begin{tabular}{ll}
\hline Hasil Gain Score & Kriteria \\
\hline Gain $>0.7$ & Tinggi \\
$0.7>=$ gain $>=0.3$ & Sedang \\
Gain $<0.3$ & Rendah \\
\hline Sumber: Hake (1998) dalam Sudyana dan Frantius [14]
\end{tabular}

Tabel 4. Kategori Tafsiran Efektivitas Gain

\begin{tabular}{ll}
\hline Persentase (\%) & Tafsiran \\
\hline$<40$ & Tidak Efektif \\
$40-55$ & Kurang Efektif \\
$56-75$ & Cukup Efektif \\
$<76$ & Efektif \\
\hline \multicolumn{2}{c}{ Sumber: Arikunto (1999) dalam Arini [15] }
\end{tabular}

\section{HASIL DAN PEMBAHASAN}

Penelitian untuk melihat efektivitas penerapan model pembelajaran kooperatif tipe jigsaw dan jigsaw berbantuan mind map terhadap kemampuan pedagogik dilakukan pada mahasiswa sejumlah 19 orang yang mengikuti mata kuliah Pengembangan Program Diklat pada semester Genap 20182019. Eksperimen tersebut menghasilkan 2 jenis data, antara lain: (a) hasil pretest dan posttest mahasiswa dan (b) hasil angket respon mahasiswa. Data tersebut kemudian diolah menggunakan statistik deskriptif dan inferensial untuk melihat pengaruh dan efektivitas penerapan model pembelajaran tersebut. 


\section{A. Pengaruh Penerapan Model Pembelajaran}

Penelitian eksperimen ini diawali dengan kegiatan pretest dan diakhiri dengan kegiatan posttest, menggunakan soal obyektif sebanyak 30 soal. Hasil kedua tes tersebut selanjutnya diolah menggunakan statistik deskriptif dan inferensial untuk mengetahui pengaruh dari variabel bebas terhadap variabel terikat. Data yang terdapat pada Tabel 5 merupakan hasil perhitungan statistik deskriptif dari hasil nilai pretest dan posttest.

Tabel 5. Data Statistik Deskriptif Hasil Pretest dan Posttest

$\begin{array}{llllc}\text { Tes } & \text { Terendah } & \text { Tertinggi } & \text { Rata-Rata } & \text { Standar Deviasi } \\ \text { Pretest } & 35 & 75 & 50,26 & 10,0655 \\ \text { Postest } & 56,67 & 90 & 78,07 & 9,642\end{array}$

Pada Tabel 5 dapat dilihat bahwa rerata pretest lebih rendah dibandingkan dengan rerata posttest. Hal ini menunjukkan bahwa secara deskriptif ada perbedaan rata-rata nilai kemampuan kognitif mahasiswa pada saat pretest dan posttest setelah pemberian perlakuan penerapan model pembelajaran kooperatif tipe jigsaw berbantuan mind map. Namun, hal tersebut belum bisa menunjukkan adanya pengaruh yang signifikan penerapan model pembelajaran terhadap peningkatan kemampuan pedagogik mahasiswa. Selanjutnya, untuk mengetahui adanya pengaruh yang signifikan diantara kedua variabel tersebut, dilakukan uji hipotesis menggunakan uji-t sampel berpasangan terhadap hasil perolehan pretest dan posttest.

Uji hipotesis tersebut dapat dilakukan jika uji asumsi klasik telah terpenuhi, yaitu data penelitian harus berdistribusi normal. Data terdistribusi secara normal dapat diketahui dari Uji Normalitas. Pada perhitungan ini, peneliti menggunakan Uji Normalitas Shapiro-Wilk. Hasil Uji Normalitas dapat dilihat pada Tabel 6.

Tabel 6. Hasil Uji Normalitas Shapiro-Wilk

$\begin{array}{llll}\text { Kelompok } & \text { Statistik } & \text { Df } & \text { Sig. } \\ \text { Pretest } & 0,908 & 19 & 0,068 \\ \text { Posttest } & 0,901 & 19 & 0,052\end{array}$

Hasil uji normalitas pada Tabel 6 menunjukkan nilai Sig. untuk kelompok pretest sebesar 0,068 dan nilai Sig. untuk Kelompok Posttest sebesar 0,052. Karena nilai Sig. dari kedua kelompok yang akan dibandingkan tersebut $>0,05$, maka dapat disimpulkan bahwa data kemampuan pedagogik mahasiswa untuk pretest dan posttest adalah berdistribusi normal, sehingga uji statistik dapat dilanjutkan dengan melakukan uji hipotesis menggunakan uji-t sampel berpasangan. Hasil Uji-t sampel berpasangan antara nilai pretest dan posttest dapat dilihat pada Tabel 7.

\begin{tabular}{lccl}
\multicolumn{4}{c}{ Tabel 7. Hasil Uji-t Pretest dan Posttest } \\
\hline Pasangan & T & Df & Sig. \\
\hline Pretes-Postes & $-9,477$ & 18 & 0,000 \\
\hline
\end{tabular}

Berdasarkan Tabel 7, nilai Sig. dari hasil uji-t sampel berpasangan antara pretest dan postest kemampuan pedagogik mahasiswa menunjukkan nilai 0,000. Dalam uji-t sampel berpasangan, jika nilai Sig. $<0,05$, maka Ho ditolak dan Ha diterima. Oleh karena hasil perhitungan menunjukkan nilai Sig. 0,000 <0,05, maka dapat dipastikan bahwa Ho ditolak, dan Ha diterima, sehingga kesimpulan dari hipotesis yang diambil adalah ada perbedaan rata-rata yang signifikan antara kemampuan pedagogik mahasiswa pada saat pretest dan postest, yang artinya ada pengaruh penerapan model pembelajaran kooperatif tipe jigsaw berbantuan mind map terhadap kemampuan pedagogik mahasiswa pada Mata Kuliah Pengembangan Program Diklat.

Mahasiswa mengalami peningkatan konsep pedagogik setelah mempelajari materi tersebut dengan menggunakan model pembelajaran kooperatif tipe jigsaw berbantuan mind map. Peningkatan konsep tersebut sesuai dengan hasil penelitian yang dilakukan oleh Sulistiawati dan Sriyati [16] yang memberikan kesimpulan bahwa model pembelajaran kooperatif tipe jigsaw dengan penugasan mind map secara signifikan dapat meningkatkan penguasaan konsep dan kemampuan berpikir kreatif peserta didik.

Penelitian yang relevan lainnya terkait dengan penerapan model pembelajaran kooperatif tipe jigsaw berbantuan mind map memberikan hasil yang sama. Penelitian sebelumnya oleh Samaela, dkk 
[17] menghasilkan simpulan serupa yaitu adanya pengaruh yang signifikan model pembelajaran kooperatif tipe jigsaw II dan teknik peta pikiran secara simultan terhadap hasil belajar peserta didik. Demikian juga dengan penelitian Octobrianta dan Utami [18] yang mengungkap bahwa terdapat pengaruh model pembelajaran kooperatif tipe jigsaw disertai mind map terhadap hasil belajar kognitif dan motivasi belajar peserta didik.

Penerapan model pembelajaran tipe jigsaw membuat mahasiswa bersungguh-sungguh dalam mempelajari materi yang dibagikan pada kelompok ahli untuk kemudian menyampaikan materi tersebut kepada teman pada kelompok asal. Mahasiswa lebih leluasa mengembangkan pengetahuan, menyatakan pendapat, serta menanyakan materi yang belum dipahami pada sesama teman dalam kelompok. Selain itu, ingatan mahasiswa tentang materi pedagogik yang dipelajari bisa bertahan lebih lama, karena mahasiswa terlibat secara langsung dalam mengkonstruksi pengetahuan [17] dan berbagi pengalaman mengenai materi yang dibahas.

Penerapan teknik mind map membantu mahasiswa dalam mengonsep ide pokok materi yang dipelajari menjadi bentuk poin-poin. Teknik ini dapat memudahkan mahasiswa dalam belajar dan menjelaskan materi kepada temannya secara tepat, runtut, dan jelas. Melalui mind map materi yang begitu banyak dapat dirinci sehingga lebih mudah untuk dipelajari, selain itu peserta didik juga dapat menuangkan berbagai ide-ide kreatifnya [17]. Penelitian oleh Fadillah [18] menyebutkan bahwa mind map memiliki beberapa keuntungan, yaitu memfasilitasi peserta didik untuk mengembangkan ide mereka mengenai materi dan membantu peserta didik untuk mengingat dan menyampaikan ide dengan lebih baik.

\section{B. Efektivitas Penerapan Model Pembelajaran}

Efektivitas penerapan model pembelajaran kooperatif tipe jigsaw berbantuan mind mapping diukur dari hasil angket respon dan nilai gain. Angket respon digunakan untuk melihat efektivitas berdasarkan respon yang diberikan mahasiswa terhadap model pembelajaran yang diterapkan. Sedangkan nilai gain digunakan untuk melihat efektivitas penerapan model pembelajaran yang diterapkan berdasarkan hasil nilai pretest dan nilai posttest.

\section{a) Efektivitas berdasarkan Respon Mahasiswa terhadap Penerapan Model Pembelajaran}

Angket respon diberikan pada mahasiswa pada saat posttest telah selesai dilakukan. Tujuan dari angket respon ini adalah untuk mengetahui respon mahasiswa terhadap model pembelajaran yang diterapkan selama kegiatan eksperimen berlangsung. Data yang dihasilkan berupa data deskriptif mengenai keterlaksanaan dan kebermanfaatan dari model pembelajaran kooperatif tipe jigsaw berbantuan mind map.

Tabel 8. Rangkuman Analisis Deskriptif Angket Respon Mahasiswa terhadap Model Pembelajaran

\begin{tabular}{lllll}
\hline Aspek Pelaksanaan & $\begin{array}{l}\text { Jumlah } \\
\text { Responden }\end{array}$ & $\begin{array}{l}\text { Rata-Rata } \\
\text { Skor Angket }\end{array}$ & $\begin{array}{l}\text { Persentase } \\
(\%)\end{array}$ & $\begin{array}{l}\text { Kriteria } \\
\text { Efektivitas }\end{array}$ \\
\hline $\begin{array}{l}\text { Model pembelajaran } \\
\text { kooperatif tipe jigsaw } \\
\text { berbantuan mind map }\end{array}$ & 19 & 3,49 & 87,21 & Sangat Efektif \\
\hline
\end{tabular}

Rangkuman hasil analisis deskriptif dari angket respon dapat dilihat pada Tabel 8. Angket respon terhadap model pembelajaran dibagikan kepada 19 mahasiswa Rombel 2 yang menjadi kelas eksperimen. Angket tersebut menggunakan jenis data berskala 4. Rata-rata skor angket dari 19 responden adalah 3,49. Jika dipersentasekan menggunakan Rumus 1 , maka menghasilkan nilai $87,21 \%$. Berdasarkan Tabel 2, maka nilai persentase rata-rata skor angket respon seluruh mahasiswa tersebut termasuk pada kriteria sangat efektif.

Jika ditinjau dari efektivitas respon setiap mahasiswa terhadap model pembelajaran yang diterapkan, maka terdapat 18 mahasiswa memberikan respon sangat efektif dan 1 mahasiswa memberikan respon efektif. Persentase respon mahasiswa terhadap efektivitas model pembelajaran yang diterapkan dapat dilihat melalui Gambar 2. Sebanyak 94,74\% mahasiswa memberikan respon sangat efektif terhadap model pembelajaran kooperatif tipe jigsaw berbantuan mind map. Sementara sisanya sebanyak $5,26 \%$ mahasiswa memberikan respon efektif. 


\section{Persentase Respon Mahasiswa Terhadap Efektivitas Model Pembelajaran}

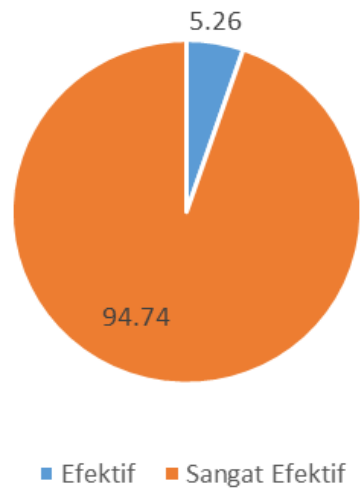

Gambar 2. Persentase Respon Mahasiswa terhadap Efektifitas Model Pembelajaran

Respon mayoritas mahasiswa terhadap penerapan model pembelajaran kooperatif tipe jigsaw berbantuan mind map adalah sangat efektif. Hal ini menunjukkan bahwa model pembelajaran yang dilaksanakan telah terlaksana dengan baik sesuai dengan tahapan-tahapannya. Selain itu, model pembelajaran juga dinilai memiliki kebermanfaatan yang sangat baik oleh mahasiswa. Kegiatan pembelajaran ini menciptakan suasana kelas yang menyenangkan, sehingga motivasi belajar mahasiswa meningkat. Hal ini juga turut diimbangi dengan kenaikan rata-rata kompetensi pedagogik mahasiswa.

Respon positif peserta didik terhadap model pembelajaran kooperatif tipe jigsaw berbantuan mind map juga terjadi pada penelitian sebelumnya. Penelitian oleh Marquez et al [19] menyebutkan bahwa sikap yang ditunjukkan oleh peserta didik selalu sangat positif, yang tercermin dalam hasil kuesioner kepuasan dengan sebagian besar peserta didik pada kelompok eksperimen merasa termotivasi oleh pengalaman selama proses pembelajaran. Implementasi mind map dapat meningkatkan motivasi belajar peserta didik [20].

\section{b) Efektivitas berdasarkan Perhitungan Nilai N-Gain dari Pretes dan Postes}

Selain digunakan dalam uij komparasi untuk mengetahui adanya pengaruh yang signifikan model pembelajaran terhadap kemampuan pedagogik, nilai pretest dan posttest dalam penelitian ini juga digunakan untuk melihat efektivitas penerapan model pembelajaran berdasarkan peningkatan nilai tes. Efektivitas ditentukan berdasarkan perhitungan nilai $\mathrm{N}$-gain dari rata-rata skor pretest dan posttest mahasiswa sebanyak 19 orang. Perhitungan nilai $\mathrm{N}$-gain dilakukan sesuai dengan Rumus 2 . Hasil perhitungan nilai gain dapat dilihat pada Tabel 9.

Tabel 9. Hasil Perhitungan Gain Score

\begin{tabular}{llll}
\hline Rata-rata pretes & Rata-rata Postes & Gain Score & Persentase \\
\hline 50,26 & 78,07 & 0,56 & $56 \%$ \\
\hline
\end{tabular}

Data pada Tabel 9 menunjukkan Nilai $N$-Gain sebesar 0,56. Berdasarkan Tabel 3 Kriteria $N$ Gain Score, nilai $N$-Gain yang diperoleh tersebut termasuk pada kriteria sedang. Sedangkan Jika dilihat dari Tabel 4, kategori tafsiran efektivitas gain berdasarkan persentase, maka perolehan $\mathrm{N}$-Gain sebesar $56 \%$ termasuk pada kategori tafsiran Cukup Efektif. Hasil penelitian menunjukkan bahwa ada peningkatan rata-rata nilai pretest dengan posttest. Hal ini sama dengan penelitian yang telah dilakukan sebelumnya. Penelitian tindakan kelas oleh Fatmawati [21] memberikan hasil bahwa penerapan jigsaw dan mind map dapat meningkatkan domain kognitif, afektif dan psikomotor peserta didik. 


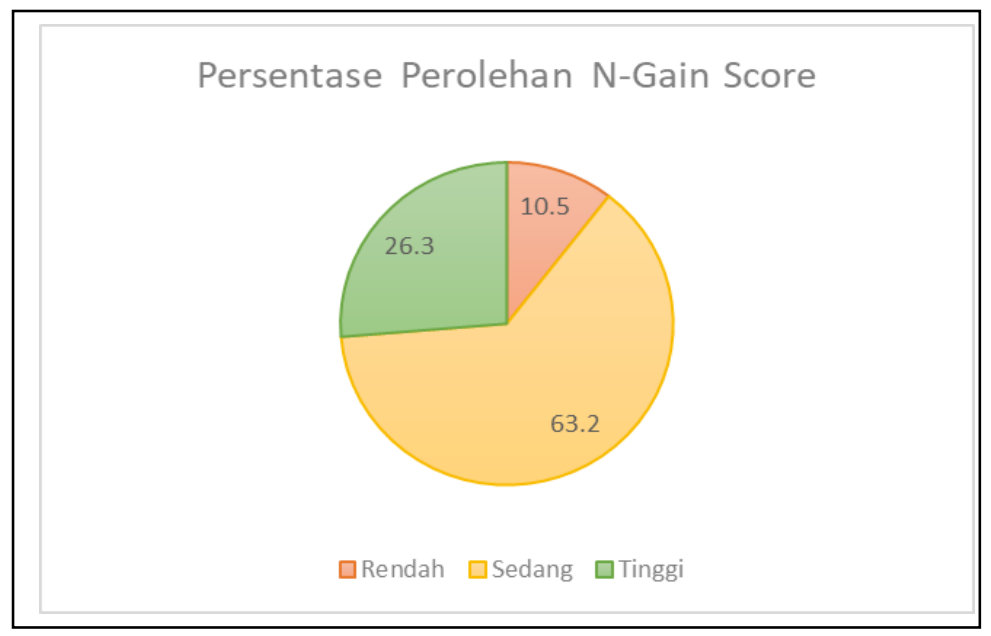

Gambar 3. Persentase Perolehan N-Gain Score Mahasiswa

Gambar 3 menunjukkan persentase perolehan N-Gain Score mahasiswa berdasarkan kategori rendah, sedang, dan tinggi. Jumlah mahasiswa yang memperoleh Nilai $\mathrm{N}$-Gain rendah sebanyak 2 orang dengan persentase $10,5 \%$ dari keseluruhan mahasiswa. Jumlah mahasiswa yang memperoleh Nilai $\mathrm{N}$-Gain sedang sebanyak 12 orang dengan persentase $63,2 \%$ dari keseluruhan mahasiswa. Sedangkan jumlah mahasiswa yang memperoleh Nilai $\mathrm{N}$-Gain tinggi sebanyak 5 orang dengan persentase $26,3 \%$ dari keseluruhan mahasiswa. Data tersebut, menunjukkan bahwa mayoritas mahasiswa memiliki peningkatan skor dalam kategori sedang dan tinggi. Berdasarkan data sebaran Nilai $\mathrm{N}$-Gain mahasiswa, rata-rata $\mathrm{N}$-Gain dan persentasenya, maka dapat disimpulkan bahwa model pembelajaran kooperatif tipe jigsaw berbantuan mind map cukup efektif dalam meningkat kemampuan pedagogik mahasiswa pada mata kuliah Pengembangan Program Diklat.

Mind map efektif untuk meningkatkan retensi peserta didik. Melalui mind map, peserta didik dapat menerima dan menyimpan informasi dalam memori jangka panjang, sehingga siswa akan dengan mudah mengingat informasi tersebut pada saat dibutuhkan [17]. Pembelajaran kooperatif tipe jigsaw berbantuan mind map memberikan pembelajaran yang lebih bermakna kepada peserta didik [19].

\section{SIMPULAN DAN SARAN}

Berdasarkan hasil penelitian dan analisis data yang dilakukan, dapat diperoleh simpulan sebagai berikut. Pertama, ada pengaruh yang signifikan dari penerapan model pembelajaran kooperatif tipe jigsaw berbantuan mind map terhadap penguasaan materi pedagogik pada mata kulian Pengembangan Program Diklat. Kedua, penerapan model pembelajaran kooperatif tipe jigsaw berbantuan mind map efektif untuk meeningkatkan kemampuan pedagogik mahasiswa pada mata kuliah Pengembangan Program Diklat, simpulan ini didukung dengan: (a) Persentase respon mahasiswa terhadap penerapan model pembelajaran sebesar $87,21 \%$, yang termasuk pada kriteria sangat efektif; (b) Persentase nilai $N$-Gain sebesar $56 \%$, yang menunjukkan bahwa model pembelajaran cukup efektif dalam meningkatkan nilai kemampuan pedagogik mahasiswa.

Adapun saran dari hasil penelitian ini yaitu (a) untuk pendidik, model pembelajaran kooperatif tipe jigsaw berbantuan mind map dapat digunakan dalam kegiatan pembelajaran, terutama untuk materi teori yang membutuhkan pemahaman lebih; dan (b) untuk peneliti lain, sebaiknya melengkapi penelitian dengan menambahkan kelas kontrol sebagai pembanding dari model pembelajaran ini.

\section{DAFTAR PUSTAKA}

[1] B. Kartowagiran. Kinerja Guru Profesional (Guru Pasca Sertifikasi). Jurnal Cakrawala Pendidikan, 2011, 30(3): 463-473.

[2] A. N. Prasetyo dan Kusumantoro. Pengaruh Kompetensi Pedagogik Guru dan Disiplin Belajar Melalui Motivasi Belajar sebagai Variabel Intervening Terhadap Prestasi Belajar. Economic Education Analysis Journal, 2015, 4(1): 16-25.

[3] A. Supriyono. The influence of Pedagogik, proffesional competency, and work motivation on 
teacher performance of Elementary School. Jurnal Pendidikan, 2017, 18(2): 1-12.

[4] Daryanto, Bintoro, dan I. Setyobudi. Manajemen Diklat. Yogyakarta: Penerbit Gava Media, 2014.

[5] P. K. Nashiroh, P. Honggowiyono, M. J. Fuady. Penerapan Model CTL berbasis NHT dan Model Pembelajaran Kooperatif Strategi Expert Group terhadap Hasil Belajar TIK. Jurnal Teknologi dan Kejuruan, 2013, 36(2): 127-136.

[6] K. R. Amalia. Effectiveness of The Implementation of Cooperative Learning Model of STAD Type with SAVI-CTL Approach in Mathematics Learning to Class VII Students at SMPN 2 Bontonompo Selatan in Gowa District. Jurnal Inovasi Pendidikan Matematika, 2018, 6(1): 6682.

[7] F. Gull and S. Shehzad. Effects of Cooperative Learning on Students' Academic Achievement. Journal of Education and Learning, 2015, 9(3): 246-255.

[8] A. Karacop and E.H. Diken. The Effects of Jigsaw Technique Based on Cooperative Learning on Perspective Science Teachers' Science Process Skill. Journal of Education and Practice, 2017, 8(6): 86-97.

[9] N.A.W. Hidayah, Suharno, M. Indriayu. The Use of Cooperative Learning of Jigsaw-Type and Make a Match Type to Improve Students' Activity. International Journal of Recent Engineering Science, 2017, 4(1): 33-37.

[10] S. Suprihatin. Pengaruh Model Pembelajaran Jigsaw terhadap Hasil Belajar Studi Masyarakat Indonesia Mahasiswa. Jurnal Pendidikan Ekonomi UM Metro, 2017, 5(1): 84-94.

[11] I. P. Roniwijaya. Pembelajaran Model Mind Map untuk Meningkatkan Aktivitas dan Hasil Belajar Kompetensi Sistem Kelistrikan dan Instrumen Siswa Kelas XI Teknik Sepeda Motor SMK Diponegoro Depok Sleman. Jurnal Taman Vokasi, 2017, 5(1): 92-105.

[12] E. Sulichah. Efektivitas Model Pembelajaran Mind Mapping terhadap Hasil Belajar IPA ditinjau dari Motivasi Belajar Siswa. Natural: Jurnal IImiah Pendidikan IPA, 2018, 5(2): 71-77.

[13] P. K. Nashiroh, W. Kamdi, H. Elmunsyah. The effectiveness of web-programming module based on scientific approach to train logical thinking ability for students in vocational high school. AIP Conference Proceedings, 2017, 1887(1): 020068-1-9.

[14] I. N. Sudyana dan D. Frantius. Efektivitas Modul Konsep Asam Basa Berorientasi Keterampilan Generik Sains. Prosiding Seminar Nasional MIPA 2016, hal 148-155.

[15] W. Arini. Efektivitas Pembelajaran Kontekstual Praktikum Mata Pelajaran Pemrograman Web Siswa Kelas X SMK Muhammadiyah 1 Bantul. Jurnal Pendidikan, 2016, hal 1-7.

[16] L. Sulistiawati, S. Sriyati. Implementasi Model Kooperatif Tipe Jigsaw dengan Penugasan Mind Map untuk Meningkatkan Penguasaan Konsep dan Kemampuan Berpikir Kreatif Siswa. Prosiding Biologi, Sains, Lingkungan, dan Pembelajarannya pada Seminar Nasional XII Pendidikan Biologi FKIP UNS, 2015, hal 212-216.

[17] D. P. Samaela, M. Jamhari, dan I. N. Kundera. Pengaruh Model Pembelajaran Kooperatif Tipe Jigsaw II dan Teknik Peta Pikiran terhadap Hasil Belajar Siswa Kelas X SMA Negeri 3 Poso pada Mata Pelajaran Biologi. Jurnal Mitra Sains, 2017, 5(2): 48-57.

[18] R. Fadillah. Students' Perception On The Use Of Mind Mapping Application Software in Learning Writing. Journal of Culture, English Language Teaching, Literature and Linguistics, 2019, 6(1): 58-64.

[19] L. M. T. Marquez, J. G. Llinas, F. S. Macias. Collaborative Learning: Use of The Jigsaw Technique in Mapping Concepts of Physics. Problems of Education in The 21 ${ }^{\text {th }}$ Century, 2017, 75(1): 92-101.

[20] Z. Z. Gagic, S. J., Skuban, B. N. Radulovic, M. M. Stojanovic, O. Gajic. The Implementation of Mind Maps in Teaching Physics: Educational Efficiency and Students' Involvement. Journal of Baltic Science Education, 2019, 18(1): 117-131.

[21] S. E. Fatmawati. The Application of Jigsaw and Mind Mapping to Increase Student'sLearning Result. Classroom Action Research Journal, 2018, 2(1): 24-29. 